\title{
HOMENAGEM A SUZANNE DAVEAU
}

A organização de um número da revista Finisterra dedicado à Professora Suzanne Daveau não é mais que uma singela homenagem a um dos vultos mais notáveis das investigações geográficas em Portugal. Francesa pelo nascimento, portuguesa pelo seu casamento, pelo interesse apaixonado que tem dedicado ao nosso país, pelos temas que tem tratado em larga parte da sua obra, Suzanne Daveau deu um impulso decisivo, a partir de meados dos anos 60, à Geografia que entre nós se pratica: renovou ou aprofundou alguns domínios de pesquisas, lançou os fundamentos de alguns outros, ajudou a consolidar uma imagem de conjunto da terra portuguesa, contribuiu de modo fundamental para a formação de muitos jovens investigadores. Durante alguns anos teve a seu cargo as tarefas executivas que permitiram dar continuidade ao Centro de Estudos Geográficos e a esta sua revista que sempre lhe mereceu um carinho muito especial; ao longo de um período de tempo bem maior assegurou, com o nível de exigência e o rigor que lhe são habituais, a orientação de duas das áreas científicas do Centro.

$\mathrm{Na}$ altura em que se ultima a preparação deste número, a Universidade de Lisboa presta também significativa homenagem a Suzanne Daveau, ao conferir-lhe o grau de Doutor honoris causa, em cerimónia solene realizada no mês de Maio de 1997, na Aula Magna da Reitoria, depois da aprovação, sempre por unanimidade, de propostas apresentadas sucessivamente na Comissão Científica de Geografia da Faculdade de Letras, no Conselho Científico da mesma Faculdade e na Comissão Científica do Senado da Universidade.

O leitor encontrará nas páginas que se seguem informação variada e minuciosa sobre a vida e a obra de Suzanne Daveau, através da recolha, quase exaustiva, dos mais diversos elementos e de alguns testemunhos de autores com diferentes formações. Junta-se um conjunto de trabalhos elaborados em sua homenagem por geógrafos portugueses e estrangeiros. No caso dos primeiros, e para evitar melindres, convidaram-se os catedráticos que com ela tiveram ocasião de trabalhar. Os poucos que, por exigências de tarefas e compromissos inadiáveis, não puderam colaborar, solicitaram-me que o seu nome ficasse inscrito numa tábula gratulatória, a inserir no começo deste volume. Acabou por se desistir da elaboração da referida tábula; na realidade, ela incluiria decerto toda a comunidade geográfica portuguesa e numerosos colegas estrangeiros, para além de especialistas em domínios próximos dos que Suzanne Daveau cultivou. De qualquer forma, fica aqui assinalada esta menção. E acrescente-se ainda que foram muitos os geógrafos não contactados que mostraram desejo de colaborar; regista-se também o seu interesse, que só não foi atendido, porque houve a intenção de circunscrever esta homenagem 
a um número da Finisterra já inicialmente previsto. Estou certo de que, dada a projecção de Suzanne Daveau, seriam necessários vários volumes para se reunirem os numerosos trabalhos que, certamente, suscitaria uma iniciativa de âmbito mais lato.

Manda um dever da mais elementar justiça que acrescente ainda o seguinte. A ideia de uma publicação deste género, concebida em homenagem à Professora Suzanne Daveau, foi apresentada, em primeiro lugar, já em 1994, por quatro dos seus discípulos, João Carlos Garcia, Júlia Galego, Maria Fernanda Alegria e Maria Helena Dias. Por motivos vários, esse projecto não foi então concretizado: mas boa parte do esquema que o guiava foi agora aproveitado.

Para além de uma homenagem, estou convicto de que o presente número da $\mathrm{Fi}$ nisterra constituirá também valioso instrumento de trabalho, de tal forma todos nós somos confrontados frequentemente com a necessidade de utilizar informações sobre a actividade e os numerosos trabalhos que compõem a bibliografia de Suzanne Daveau. Prevalece, porém, o intuito de lhe consignar aqui a profunda admiração e o maior reconhecimento, por parte de todos os que com ela trabalharam e conviveram, por parte dos geógrafos portugueses em geral.

Carlos Alberto Medeiros Director da Finisterra 